\title{
Türkçe Öğretmeni Adaylarının Tweet Atma Becerileri Üzerine Bir Araştırma
}

Talat AYTAN1

\author{
Gökhan GÜNEŞ²
}

\section{Mehmet Ali ÇALICI3}

\begin{abstract}
$\ddot{\mathbf{O} z}$
Bireyin zihinsel, duygusal ve sosyal becerilerini geliştirmeyi esas alan eğitim, çağın enerjisine veya zamanın ruhuna göre değişimler gösterebilmektedir. İnsanlık tarihinde tarım ve sanayi devriminden sonra en etkili dönüm noktası bilişim devrimi olmuştur. Yirmi birinci yüzylldaki teknolojik gelişmelere koşut olarak farklı yazarlık türlerinin oluştuğu bilinmektedir. Bu bağlamda kâğıt temelli yazma çalışmaları yerini yavaş yavaş elektronik yazmaya bırakmaktadır. Yenilenen öğretim programları da bu değişimi göz önünde bulundurarak e-posta, blog vs. gibi ekran yazma becerilerine ait türlere yer vermektedir. Bu araştırmanın amacı, Türkçe öğretmeni adaylarının bir sosyal medya uygulaması olan Twitter kanalıyla tweet atma becerilerini, okudukları farklı metin türlerinden hareketle anahtar kelimeleri kullanma becerileri açısından incelemektir. Çalışma grubunu İstanbul'daki bir devlet üniversitesinin Türkçe eğitimi bölümünde öğrenim gören 36 öğretmen adayı oluşturmaktadır. Çalışma grubundaki öğretmen adaylarına "haber metni, küçürek öykü, köşe yazısı, anı ve deneme" türlerinde birer metin okutulmuş, metinden anladıklarını Twitter uygulamasının bir sinırllığı olan 140 karakterle ifade etmeleri istenmiştir. Araştırmanın sonuçlarına göre, Türkçe öğretmeni adaylarının deneme ve köşe yazısı türlerinde daha başarılı olduğu; haber, küçürek öykü ve anı metninde ise başarılarının daha düşük seviyede olduğu tespit edilmiştir. Genel anlamda Türkçe öğretmeni adaylarının 3 ve üzerinde anahtar kelimeyi kullanamadıkları görülmüş, bu sebeple okudukları bir metinden hareketle çıkarımlarını yazılı olarak ifade etmede zorlandıkları sonucuna varılmıştır.
\end{abstract}

Anahtar kelimeler: Türkçe öğretmeni adayları, tweet, twitter, anahtar kelime.

\section{A Study on Writing Tweet Skills of Turkish Language Teacher Candidates}

\begin{abstract}
Education which is structured to improve individuals mental, emotional and social skills, can undergo changes based on today's dynamics or the soul of the time. In the history of humanity, after the industrial and agricultural revolution, informatics revolution has become the most effective milestone. It is known that different types of authorship have occurred concurrently with technological development in the twenty-first century. In this respect, paper based writing studies have been progressively replaced with electronic writing. Taking this change into consideration even education programs that were renewed include e-mail, blog etc that belong to on-screen writing skills. The aim of this research is to analyze Turkish language teacher candidates' twit skills via a social media platform Twitter and to analyze the use of keywords based on different reading subjects. Thirty
\end{abstract}

$1 \quad$ Dr. Öğr. Üyesi Talat Aytan, Yıldız Teknik Üniversitesi, Türkçe Eğitimi Ana Bilim Dalı, talataytan@gmail.com [Makale kaylt tarihi: 15.3.2018-kabul tarihi: 14.4.2018]

Yıldız Teknik Üniversitesi, Sosyal Bilimler Enstitüsü, Türkçe Eğitimi ABD YL Öğrencisi, gunesgkhan@gmail.com Yıldız Teknik Üniversitesi, Sosyal Bilimler Enstitüsü, Türkçe Eğitimi ABD, YL Öğrencisi, mehmetaliclc@gmail.com 


\begin{abstract}
six teacher candidates who study at the department of Turkish Education in a state university in Istanbul compose the research group. Turkish teacher candidates in working groups were asked to read news text, reduced story, opinion column, memoir and essay genres and to express what they understood from the text, in 140 character which is a restriction of the Twitter application. According to the results of the research, it is understood that Turkish language teacher candidates are more successful in literary genres like essay and opinion column while the level of success in short story and memoir is lower. On the whole it has been observed that Turkish teacher candidates can not use three or more than three keywords; therefore, it has been concluded that they have difficulty in stating their inferences in a written way in the direction of a text which they read.
\end{abstract}

Key words: Turkish teacher candidates, tweet, twitter, key word.

\title{
Giriş
}

Yirmi birinci yüzyllın hayati becerileri olarak ifade edilen eleştirel düşünme, iletişim, işbirliği ve yaratıcıllk vb. (Wagner, 2008) arasında özellikle iletişim becerisi dört temel dil becerisi ile doğrudan ilişkilidir. Bilgi (enformasyon) çağı olarak adlandırılan günümüz artık bir beceri çağına doğru ilerlemektedir. Bu sebeple bireylerin dört temel dil becerisini kullanma yetkinlikleri de her geçen gün daha fazla önem kazanmaktadır. Yirmi birinci yüzyll, dinlerken okurken ve konuşup yazarken ifade edilenleri doğru anlayıp anlatmak istediklerini de açık ve net ifade edebilen bireylere ihtiyaç duymaktadır.

İnsanoğlu var olduğundan bu yana çevresini anlama çabası içindedir. Anlama çabası insan için daha dünyaya adım atmadan anne karnında başlamaktadır. Bebeğin anne karnında edindiği ilk dil becerisi dinlemedir (Arıcı, 2016; Kurudayığlu ve Kana, 2013; Melanlığlu, 2012, Umagan, 2007) Anne karnında başlayan anlama çabası dünyaya geldikten sonra da devam eder. Dinleme ile başlayan anlama çabasının bir başka önemli basamağı da okumadır. Okuma, fiziksel süreçler ile zihinsel süreçlerin birlikte işletildiği karmaşık bir eylem olarak tanımlanabilir (Kavcar, Oğuzkan, Sever, 1998; Saraçoğlu, 2000; Sever, 2004; Arıcı, 2005; Aytaş, 2005; Karatay, 2010). Okuma sürecinde kişi gördüklerini zihninde anlamlandırmaya ve kavramaya çalışır. Okumanın sorunsuz gerçekleşebilmesi için bu süreçteki fiziksel ve zihinsel unsurlar doğru şekilde işletilmelidir; çünkü bu unsurlar doğru bir okumanın ön koşuludur. Bir anlamlandırma süreci olan okuma sağlıklı bir iletişim için de oldukça önemlidir. Okuduklarını doğru anlayan bireyler anladıklarını da daha doğru yansıtarak iletişimin bir başka önemli boyutu olan anlatmaya geçeceklerdir. Anlama çabasına dinleme ile başlayan insan anlatma çabasına da önce konuşma ile başlar. Öğrenim çağı ile de insanoğlunun tarihteki en büyük keşfi olan yazı ile tanışır. Akyol (2000) yazıyı sembol ve işaretleri belli kurallar çerçevesinde kullanarak düşünce üretimi olarak tanımlarken Arıcı (2008) yazının geçmişin bilgi birikimini gelecek kuşaklara aktaran mühim bir buluş olduğunu dile getirmektedir. Yazmak önemli olduğu kadar aynı zamanda da zor bir beceri olarak görülmektedir. Nitekim Çamurcu (2011) yükseköğrenime yeni başlayan Türkçe öğretmeni adaylarının yazma becerisi üzerine yaptığı araştırmasında Türkçe öğretmeni adaylarının duygu ve düşüncelerini yazılı olarak ifade edebilme becerisinin yeterli düzeyde olmadığı tespitinde bulunmuştur. Arıcı (2008) üniversite öğrencilerinin yazılı anlatım hatalarını irdelediği çalışmasında öğrencilerin yazılarında ana fikir ve yardımcı fikirleri oluşturmada zorlandıklarını belirtmiştir. Bağcı (2010) da Türkçe öğretmeni adaylarının yazılı anlatım bilgisi açısından başarılı olduklarını fakat bu bilgilerini yazılı anlatım becerisine yeterli seviyede dönüştüremediklerini ifade etmiştir. 
A Study on Writing Tweet Skills of Turkish Language Teacher Candidates / T. Aytan, G. Güneş, M. A. Çalıcı (p. 42-58)

Okuma yazmanın çağın koşullarına uyum süreci fonksiyonel (işlevsel) okuryazarlık kavramını ortaya çıkarmıştır. Fonksiyonel okur-yazarlık teknik ve işlevsel becerilerin bir harmanıdır (Güneş, 1994). Bağcı (2010) fonksiyonel okur-yazarlı̆̆ı çă̆ın gerekliliği olarak kabul ederek bu tür bireylerin seri okuyup anladıklarını ve bunu da hayat kalitesini artırmada kullandıklarını dile getirmektedir. Fonksiyonel okuryazarlığı edinen bireyler multifonksiyonel (çokluişlevsel) okur-yazarlığa da geçebileceklerdir. Multifonksiyonel okur-yazarlıkta bireyler okuma-yazma becerilerini kullanarak kendini geliştirme ve toplumsal bir fayda güderek kendini gerçekleştirme yolunda ilerler (Güneş, 1994).

Teknoloji ile birlikte okur-yazarlık kavramının alanı da genişlemiştir. Özellikle kâğıt medeniyetinden ekran medeniyetine doğru bir geçişin olduğu günümüzde okuma ve yazma eylemi çoğu kez internet vasıtasıyla çeşitli ortamlarda gerçekleşmektedir. Eğitim ortamlarının da bu araçlardan faydalanma sıklığı giderek artmaktadır. Eğitim ortamlarında kullanılabilecek teknolojilerin başında Web 2.o araçları gelmektedir. Web 2.0, araştırmacılar tarafından farklı şekillerde tanımlanmıştır. Atıcı ve Yıldırım'a (2010) göre Web 2.0 kullanıcılar arasında işbirliğini ve etkileşimi sağlayan, kullanıcılara içerik oluşturma ve oluşturulmuş içeriklere müdahale imkânı veren ortamlardır. Web 2.0; etkileşimi, işbirliğini ve paylaşımı ön plana çıkaran, merkeze kullanıcıları alan web ortamıdır (Deperlioğlu ve Köse, 2010). Web 2.0, iletişimi ve etkin katılımı ön plana çıkaran yenilikçi ve özgürlükçü bir ortamdır (Aslan, 2007).

Web 2.o araçları ile oluşturulan ortamlar kullanıc merkezli olmaları, kullanıcıların bilgi üretimine katılması ve kullanım kolaylığı ile ön plana çıkar (Aslan, 2007). Web 2.0 araçları öğrencileri ve öğretmenleri sadece web okuru olmaktan çıarıp web okuryazarı hâline getirmiştir (Horzum, 2010). Bu durum kullanıcıların içerik üretmesi ve üretilen içerikleri tüketmesiyle açıklanabilir.

Web 2.o teknolojileri yardımıyla oluşturulacak çevrimiçi ortamlar yüz yüze eğitimi destekleyecek ve çok yönlü bir eğitim ortamı oluşturacaktır (Deperlioğlu ve Köse, 2010). Bu teknolojilerin okul dışında öğrenciler ve öğretmenler tarafından etkin kullanılması bu durumu mümkün kılmaktadır.

Web 2.0 araçları sayesinde öğretmen dersi daha etkin bir şekilde ve canlı işleyebilir, güncel ve günlük hayatla ilgili içeriklerle daha çok dikkat çekebilir (Özerbaş ve Akın Mart, 2017). Ayrıca Web 2.o araçları, öğretmenlerin öğrencilerin bilgiyi nasıl yapılandırdığını ve öğrenme sürecini takip etmelerini sağlaması bakımından da önemlidir (Horzum, 2010).

Özdemir'e (2017) göre Web 2.0 araçları Türkçe dersinde dört temel dil becerisinin geliştirilmesinde kullanılabilir. Aytan ve Başal (2015) tarafından yapılan çalışmada Türkçe öğretmeni adaylarının Web 2.0 araçlarını iletişim ve dil becerilerinin gelişimi açısından önemli gördükleri ortaya konmuştur. Web 2.0 araçlarının kullanıcıları aktif kılması ve içerik üretme ve tüketme imkânı sağlaması dil becerilerini doğrudan kullanılmasını gerektirmektedir. İçerik üretimi noktasında yazma ve konuşma, içerik tüketimi noktasında ise okuma ve dinleme becerileri işe koşulmaktadır.

Web 2.0 araçlarından olan sosyal ağlar insan yaşamını en çok etkileyen kavramlardandır (Koç ve Ayık, 2017). Bu etkileme eğitim alanına da tesir etmektedir. Gülbahar, Kalelioğlu ve Madran'a (2010) göre sosyal ağ siteleri insanların öğrenme sürecini yeniden şekillendirmiştir. Sosyal ağlar sayesinde aktif, yaratıcı, işbirlikçi, öğretmen-içerik-öğrenci arasında karşılıklı etkileşime dayalı eğitim ortamları oluşturulabilir. 
Türkiye'de en çok kullanılan sosyal ağlardan biri Twitter'dır. 2006 yılından bu yana kullanılan Twitter, kullanıcılarına hızlı ve kolay bir şekilde ileti paylaşma imkânı tanır. İletiler genellikle metindir (Köse ve Çal, 2012). Twitter, Eryılmaz'a göre belirli grup ve sınıfları bir konu etrafında toplamak ve çeşitli paylaşımlar yapmak için kullanılabilir. Twitter, kullanıcıların iletişim kurmasını ve bilgi alışverişinde bulunmasını sağlayan sosyal bir ağdır (Karademir ve Alper, 2011). Twitter, kullanıcıların duygularını ve düşüncelerini paylaşabilecekleri, başka görüşlere de saygılı olmayı gerektiren, iletişim ve paylaşım odaklı bir ortamdır (Günüç, Odabaşı ve Kuzu, 2013). Kullanıcılarına bilgi, duygu ve düşünceleri 140 karakterle sınırlı paylaşma imkânı sunması Twitter'a hem bir sosyal ağ hem de mikroblog özelliği yüklemektedir (Odabaşı ve diğerleri, 2012).

Twitter'da oluşturulan iletiye tweet denir. Özbaş Anbarlı'ya (2017) göre tweet, Twitter'da kullanıcıların 140 karakter sınırlamasına bağlı kalarak üretip ara yüze yazdığı içeriktir. Twitter'da oluşturulan bir iletinin kısa, öz ve dikkat çekici olması beklenmektedir (Kuzu, 2014). Twitter'ın kullanıcıların ürettikleri içeriği 140 karakterle sinırlaması ilk bakışta olumsuz bir algıya sebep olabilir ancak bu durumun kullanıcıya oluşturduğu ileti üzerine daha çok düşünme, iletisinin anlamı ve kapsamı üzerine eleştirel yaklaşma gibi faydaları olacağı açıktır. Öte yandan Twitter'ın 2017 Kasım ayı itibariyle karakter sayısını 280’e çıkardığı da bilinmektedir.

Twitter'ın öğrenciler, farklı ilgileri olan insanlar ve profesyonel çalışanlar tarafından kullanılıyor olması, insanlar arasında iletişime imkân tanıması, kullanıcıların ilgi alanlarına göre kişileri ve toplulukları takip etmesini mümkün kılması, Twitter'ı eğitimde kullanılmaya uygun hâle getirmektedir. Bu özellikleriyle Twitter bir öğrenme ortamı olarak çevrimiçi öğrenme, mobil öğrenme, durumlu öğrenme, sosyal bilişsel öğrenme, bağlantıcı öğrenme, işbirlikli öğrenme, akrandan öğrenme kuramlarıyla ilişkilidir (Odabaşı ve diğerleri, 2012). Twitter, güncel olayları ve haberleri takip etmek, düşünce paylaşmak, bir olayı veya kişiyi takip etmek, dil, öğrenmek, tartışmak ve işbirliği amacıyla eğitim ortamlarında kullanılabilir (Gülbahar, Kalelioğlu ve Madran, 2010).

Teknolojinin gelişimi ve eğitim ortamları için fırsatlar sunmasıyla güncellenen öğretim programları da gelişen bu teknolojilere kayıtsız kalmamıştır. 2017 yılında yayımlanan ve 2017-2018 eğitim öğretim yılında 1 ve 5. sınıflarda uygulanmaya başlanan Türkçe Dersi Öğretim Programı'nda Türkiye Yeterlilikler Çerçevesi'nde sekiz yetkinlik alanı yer almıştır. Bu yetkinlik alanlarından biri de "dijital yetkinlik"tir. Bu yetkinlik alanında "bilgi ve iletişim teknolojisi içinde bilgiye erişim ve bilginin değerlendirilmesi, saklanması, üretimi, sunulması ve alışverişi için bilgisayarların kullanılması, ayrıca internet aracılığıyla ortak ağlara katılım sağlanması ve iletişim kurulması (s.6)" beklenmektedir. Bu hususlar, ismi programda zikredilmemiş olsa da Web 2.0 araçlarını akla getirmektedir. Ayrıca "Türkçe Dersi Öğretim Programı'nın Genel Amaçları" bölümünde "bilgiye erişme, bilgiyi düzenleme, sorgulama, kullanma ve üretme becerilerinin geliştirilmesi (s. 10)" bir amaç olarak yer almıştır.

Türkçe Dersi Öğretim Programı (2017) ders işlenişinde öğretmen ve öğrencileri teknoloji kullanmaya yöneltmektedir. Programda yer verilmesi öngörülen temalar ve bu temalarla ilgili konu önerileri incelendiğinde teknolojiyle ilgili olan "dijital okuryazarlık, e-kitap, teknoloji okuryazarlığı, kitle iletişim araçları, medya okuryazarlığı, bilişim okuryazarlığı, sosyal medya, dijital oyunlar (s. 18-19)" konuları dikkat çekmektedir. Ayrıca programda yer verilmesi gereken türler içinde "blog, e-posta ve sosyal medya mesajları"nın da yer alması programın günümüzün sık kullanılan teknolojilerinin eğitim ortamlarında kullanılmasına aracı olduğunu göstermektedir. Türkçe Dersi Öğretim Programı'nda (2017) bulunan bu yaklaşım, yeni yayımlanan ve 2018-2019 eğitim öğretim yılında uygulanması planlanan Türkçe Dersi Öğretim Programı'nda (2018) da korunmuştur. 
2017-2018 eğitim-öğretim yılında kullanılmakta olan 5. Sınıf Türkçe Ders Kitabı'nda (MEB, 2017) da açıkça tweet yazılması belirtilmemiş olsa da öğrencilerin öncelikle bir e-posta yazmaları ardından da epostalarını en fazla 140 karakter kullanarak tekrar yazmaları istenmiştir (s. 126-127). Twitter, Avustralya İngilizce Öğretim Programında da kendine yer bulmuştur. Programda "Twitter gibi iletişim teknolojilerinin dilinin yazılar üzerine etkisini araştırma/sorgulama (s. 188)" kazanımına yer verilmiştir (Süğümlü, 2013). Günlük hayatın ayrılmaz bir parçası hâline gelen Twitter vb. sosyal ağların öğrenciler tarafından doğru ve etkili kullanımının öğrenilmesi için ders kitaplarında ve öğretim programlarında buna benzer etkinliklerin ve kazanımların yer alması olumlu karşılanmaktadır.

Bir metnin anlaşılmasını ve hatırlanmasını kolaylaştıran çağrışım gücü yüksek kelimelere anahtar kelime denir (MEB, 2006). Türkçe öğretiminde metnin anahtar kelimelerinin tespit edilmesi ya da verili anahtar kelimelerle metin oluşturulması anlama ve anlatma becerilerinin geliştirilmesi açısından önemlidir. Bu araştırmada araştırmacılar tarafindan belirlenen anahtar kelimelerin Web 2.0 ortamında (Twitter) Türkçe öğretmeni adayları tarafından metin oluşturulurken kullanılıp kullanılmadığı sınanmıştır. Türkçe öğretmeni adaylarına metinler okutulurken okuduğunu anlama ve anahtar kelimeleri zihinde belirleyebilme becerisi; Twitter uygulamasında metinden anladıklarını ifade edebilmeleri noktasında ise yazma becerisi ön plana çlkmıştır. Temel dil becerilerinin birbirini bütünleyen beceriler olduğu düşünüldüğünde araştırmanın Türkçe öğretmen adaylarının anlama ve anlatma becerilerini odak noktası olarak kabul etmesi yönüyle önemli olduğunu dile getirmek mümkündür.

\section{Yöntem}

\section{Araştırmanın amacı}

Bu araştırmanın amacı Türkçe öğretmeni adaylarının okudukları metinlerden anladıklarını anahtar kelimeleri kullanarak 140 karakter sınırı içerisinde yazılı olarak ifade edebilme düzeyini ortaya koymaktır. Türkçe öğretmeni adaylarının 140 karakter ile sınırlandırılması günümüzde çok sık kullanılan ve bir Web 2.0 aracı olan Twitter uygulamasının bir tasarrufudur.

\section{Araştırmanın modeli}

$\mathrm{Bu}$ araştırma nitel araştırma yöntemlerinden olan doküman incelemesi modeli ile tasarlanmıştır. Doküman incelemesi, araştırılması hedeflenen olgu veya olgular hakkında bilgi içeren yazılı materyallerin analizini kapsar (Yıldırım ve Şimşek, 2016: 189). Bu araştırma İstanbul'daki bir devlet üniversitesinde öğrenim gören 36 Türkçe öğretmeni adayı, öğretmen adaylarına okutulan beş metin türü ve adayların metinden anladıklarını ifade ettikleri 140 karakterlik tweetlerle sınırlıdır. Araştırma gerçekleştirildikten sonra Twitter uygulaması, 140 karakter sınırlamasını 280 karaktere çıkarmıştır.

\section{Çalışma grubu}

Araştırmanın çalışma grubunu İstanbul'daki bir devlet üniversitesinin Türkçe Eğitimi Bölümünde öğrenim gören $26 \mathrm{kız} \mathrm{ve} 10$ erkek öğrenci oluşturmaktadır. 1.sınıfta öğrenim gören Türkçe öğretmeni adaylarının seçilmesinde yaş itibariyle teknoloji ve Web 2.0 araçlarına daha yakın oldukları düşüncesi etkili olmuştur. Araştırmada cinsiyet değişkeni üzerinden değerlendirme yapılmamıştır. 


\section{Verilerin toplanması ve analizi}

Araştırmanın verileri Türkçe öğretmeni adaylarının attıkları tweetlerden elde edilmiştir. Türkçe öğretmeni adaylarına bir haber metni, bir küçürek öykü, bir anı, bir deneme ve bir köşe yazısı verilerek metinlerin ana fikirlerini 140 karakter (tweet) ile ifade etmeleri istenmiş, sonra öğrencilerin ifadeleri incelemeye tabi tutulmuştur. Türkçe öğretmeni adaylarının attıkları tweetlerde anahtar kelimeler sayısal olarak betimlenirken araştırmacılar tarafından tayin edilen anahtar kelimelere eş ya da yakın anlamlı kelimeler de doğru olarak kabul edilmiştir.

Araştırmada kullanılan metinler katılımcılara bir Web 2.0 aracı olan Edmodo üzerinden gönderilmiş ve katılımcllardan metinleri okuyup ana düşünceyi en çok 140 karakterle ifade etmeleri istenmiştir. Her metin için katılımcılara bir gün süre tanınmıştır. Katılımcılar yirmi dört saat içerisinde istedikleri yerde ve zamanda çalışmaya katılmıştır.

Veriler betimsel analiz yöntemi ile analiz edilmiştir. Bu tür analizde amaç, elde edilen bulguları düzenlenmiş ve yorumlanmış bir biçimde okuyucuya sunmaktır. Bu amaçla elde edilen veriler, önce sistematik ve açık bir biçimde betimlenir. Daha sonra yapılan bu betimlemeler açıklanır ve yorumlanır, neden-sonuç ilişkileri irdelenir ve birtakım sonuçlara ulaşılır (Yıldırım, Şimşek, 2016: 239).

\section{Bulgular ve Yorum}

Tablo 1. Haber metni ile ilgili tweetlere ilişkin sayısal veriler

\begin{tabular}{|c|c|c|c|}
\hline Öğrenciler & 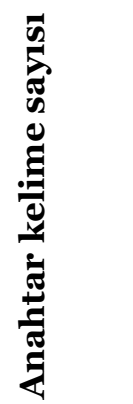 & Öğrenciler & 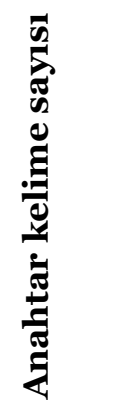 \\
\hline Ö1 & 1 & Ö19 & 1 \\
\hline Ö2 & o & Ö2o & 1 \\
\hline Ö3 & 1 & Ö21 & 1 \\
\hline$\ddot{O}_{4}$ & 1 & Ö22 & 3 \\
\hline Ö5 & 1 & Ö23 & 1 \\
\hline Ö6 & 1 & Ö24 & 1 \\
\hline$\ddot{\mathbf{O}}_{7}$ & 1 & Ö25 & o \\
\hline Ö8 & 1 & Ö26 & 0 \\
\hline Ö9 & 1 & 0̈27 & 1 \\
\hline
\end{tabular}




\begin{tabular}{|c|c|c|c|}
\hline Ö10 & 1 & Ö28 & 1 \\
\hline$\ddot{O}_{11}$ & 0 & Ö29 & 1 \\
\hline$\ddot{O}_{12}$ & 0 & Ö30 & o \\
\hline Ö13 & 0 & Ö31 & 1 \\
\hline Ö14 & 1 & Ö32 & $\mathrm{o}$ \\
\hline Ö15 & 2 & Ö33 & 0 \\
\hline Ö16 & 2 & Ö34 & $\mathrm{O}$ \\
\hline Ö17 & 1 & Ö35 & 1 \\
\hline Ö18 & o & Ö36 & 1 \\
\hline
\end{tabular}

\section{Şekil 1. Haber metni ile ilgili tweetlere ilişkin yüzdelik dağılım}

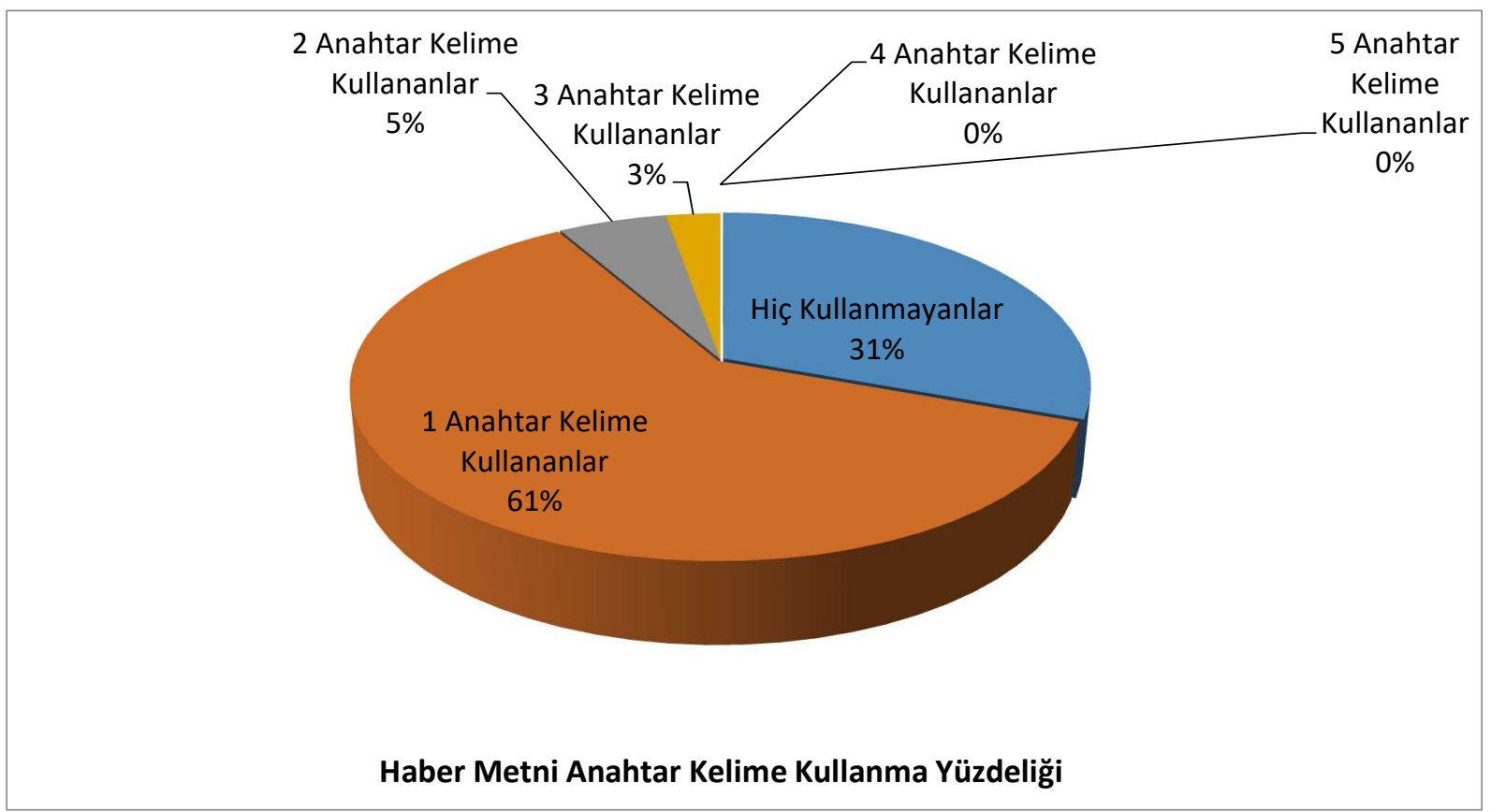

Tablo 1 ve Şekil 1'de görüldüğü gibi haber metnine dair atılan tweetlerde 22 öğrenci 1 anahtar kelime, 2 öğrenci 2 anahtar kelime, 1 öğrenci 3 anahtar kelime kullanmıştır. 10 öğrencinin hiçbir anahtar kelimeyi tweetlerinde kullanmadığı; 4 ve 5 anahtar kelime kullanan öğrencinin de bulunmadığı tespit edilmiştir. Öğrencilerin \%61’i 1 anahtar kelime, \%5’i 2 anahtar kelime, \%3’ü 3 anahtar kelime kullanmıştır. Öğrencilerin \%31’inin hiçbir anahtar kelimeyi kullanmadığı görülmektedir. Bir metnin bütününü yansıtan özet parçalar olan anahtar kelimelerin öğrencilerin tweetlerine tam olarak yansımadığı saptanmıştır. Tweetlerinde anahtar kelime kullanmayan öğrenciler ile 1 anahtar kelime kullanan öğrenciler, haber metni ile ilgili tweet atan öğrencilerin \%94’ünü oluşturmaktadır. Bu sebeple haber metninde anahtar kelime kullanabilme başarısının düşük olduğu söylenebilir. 
RumeliDE Dil ve Edebiyat Araştırmaları Dergisi 2018.11 (Nisan)/ 49

Türkçe Öğretmeni Adaylarının Tweet Atma Becerileri Üzerine Bir Araştırma / T. Aytan, G. Güneş, M. A. Çalıcı (42-58. s.)

Tablo 2. Küçürek Öykü ile ilgili tweetlere ilişkin sayısal veriler

\begin{tabular}{|c|c|c|c|}
\hline Öğrenciler & 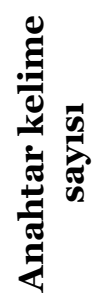 & Öğrenciler & 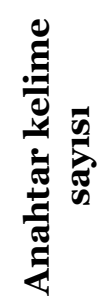 \\
\hline$\ddot{O ̈}_{1}$ & o & $\ddot{O}_{19}$ & 2 \\
\hline Ö2 & 2 & Ö20 & 1 \\
\hline Ö3 & 1 & Ö21 & o \\
\hline$\ddot{O}_{4}$ & 1 & Ö22 & o \\
\hline$\ddot{0}_{5}$ & 1 & Ö23 & 2 \\
\hline Ö6 & o & Ö24 & 1 \\
\hline$\ddot{0}_{7}$ & 1 & Ö25 & 1 \\
\hline 0̈8 & 1 & Ö26 & 1 \\
\hline Ö9 & 1 & Ö27 & 1 \\
\hline Ö10 & o & Ö28 & 1 \\
\hline Ö11 & 2 & Ö29 & 1 \\
\hline Ö12 & $\mathrm{o}$ & Ö30 & 1 \\
\hline Ö13 & 1 & Ö31 & 2 \\
\hline Ö14 & o & Ö32 & 1 \\
\hline Ö15 & $\mathrm{o}$ & Ö33 & 2 \\
\hline Ö16 & o & Ö34 & o \\
\hline Ö17 & 1 & Ö35 & 0 \\
\hline Ö18 & 1 & Ö36 & o \\
\hline
\end{tabular}




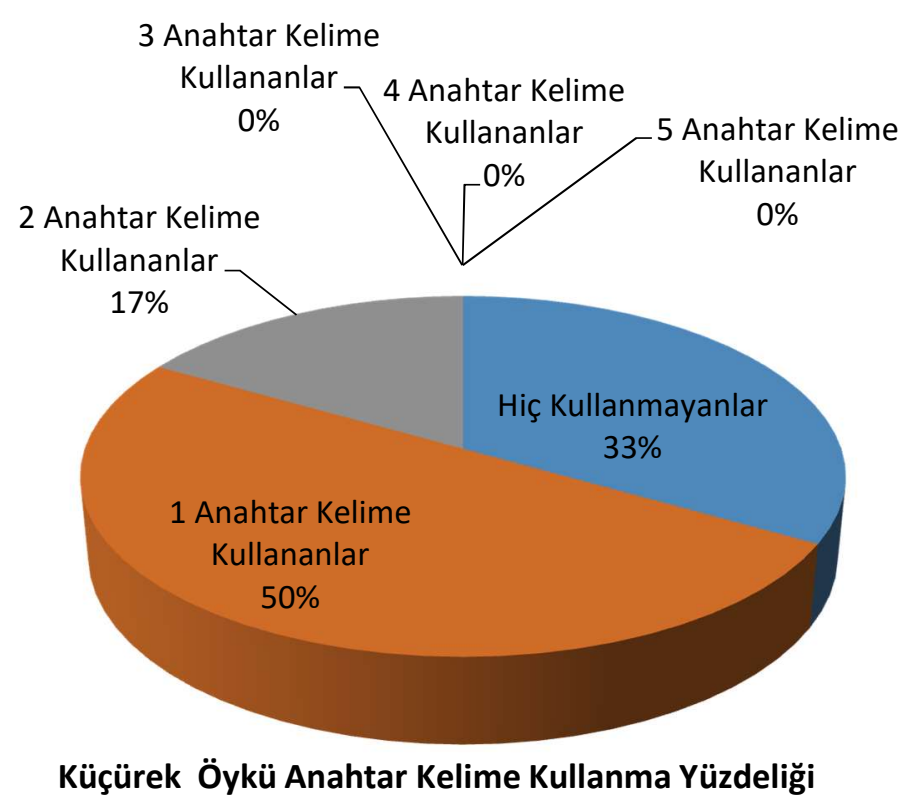

\section{Şekil 2. Küçürek Öykü ile ilgili tweetlere ilişkin yüzdelik dağılım}

Tablo 2 ve Şekil 2'de küçürek öyküye dair atılan tweetlerde 18 öğrencinin 1 anahtar kelime, 6 öğrencinin 2 anahtar kelime kullandığı, 12 öğrencinin de hiçbir anahtar kelimeyi kullanmadıkları görülmektedir. 3, 4 ve 5 anahtar kelime kullanan öğrenci bulunmamaktadır. Öğrencilerin \%50'si 1 anahtar kelime, \% 17'si 2 anahtar kelime kullanırken \%33'ü hiç anahtar kelime kullanmamıştır. Küçürek öykü tweetlerinde anahtar kelime kullanmayan öğrenciler ile 1 anahtar kelime kullanan öğrencilerin \%83’ü oluşturduğu görülmektedir. Küçürek öyküde de öğrencilerin anahtar kelimeleri ifadelerine yansıtma başarılarının düşük seviyede olduğu söylenebilir.

Tablo 3. Köşe yazısı ile ilgili tweetlere ilişkin sayısal veriler

\begin{tabular}{|c|c|c|c|}
\hline Öğrenciler & 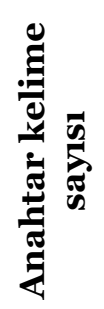 & Öğrenciler & 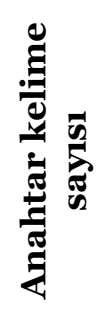 \\
\hline Ö1 & 1 & Ö19 & 1 \\
\hline Ö2 & 2 & Ö2o & 2 \\
\hline$\ddot{O}_{3}$ & 1 & Ö21 & 2 \\
\hline$\ddot{O}_{4}$ & $\mathrm{o}$ & Ö22 & 3 \\
\hline
\end{tabular}




\begin{tabular}{|c|c|c|c|}
\hline Ö5 & 1 & Ö23 & 3 \\
\hline 0̈6 & 2 & Ö24 & 1 \\
\hline$\ddot{\mathbf{O}}_{7}$ & 1 & Ö25 & 2 \\
\hline Ö8 & 1 & Ö26 & 1 \\
\hline Ö9 & 1 & Ö27 & 2 \\
\hline Ö10 & 2 & Ö28 & 2 \\
\hline Ö11 & 2 & Ö29 & 3 \\
\hline$\ddot{O}_{12}$ & 1 & Ö30 & 3 \\
\hline$\ddot{O}_{13}$ & 1 & Ö31 & 1 \\
\hline$\ddot{O}_{14}$ & 3 & Ö32 & 1 \\
\hline$\ddot{O}_{15}$ & 1 & Ö33 & 3 \\
\hline Ö16 & 2 & Ö34 & 2 \\
\hline$\ddot{O}_{17}$ & 2 & Ö35 & 4 \\
\hline$\ddot{O}_{18}$ & 1 & Ö36 & 1 \\
\hline
\end{tabular}

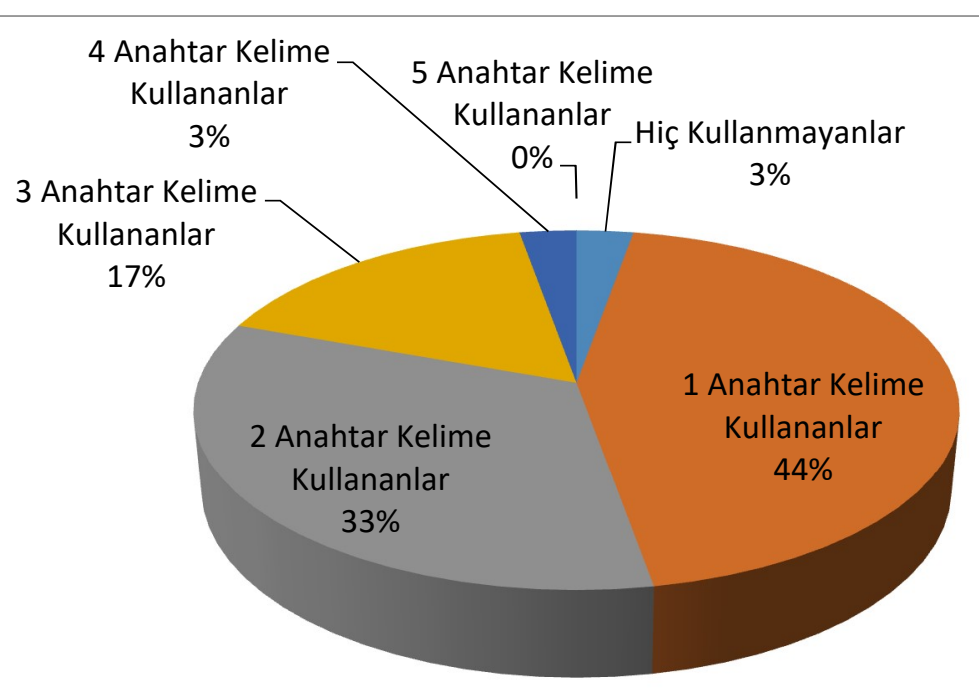

Köşe Yazısı Anahtar Kelime Kullanma Yüzdeliği

Şekil 3. Köşe Yazısı ile ilgili tweetlere ilişkin yüzdelik dağılım 
Tablo 3 ve Şekil 3’te köşe yazısına dair atılan tweetlerde 16 öğrencinin 1 anahtar kelime, 12 öğrencinin 2 anahtar kelime, 6 öğrencinin 3 anahtar kelime, 1 öğrencinin 4 anahtar kelime kullandığı, 1 öğrencinin hiçbir anahtar kelime kullanmadığı görülürken 5 anahtar kelimeyi kullanabilen öğrenci bulunmamaktadır. Öğrencilerin \%44’ü 1 anahtar kelime, \%33’ü 2 anahtar kelime, \%17'si 3 anahtar kelime, \%3’ü 4 anahtar kelime kullanırken \%3’ü ise hiçbir anahtar kelimeyi kullanmamıştır. Köşe yazısı tweetlerinde anahtar kelime kullanmayan öğrenciler \%3’ü en az bir tane olmak kaydıyla anahtar kelime kullanan öğrenciler ise \%97'yi oluşturmaktadır. 5 anahtar kelimenin tamamını kullanan öğrenci olmasa da öğrencilerin köşe yazısına dair attıkları tweetlerde anahtar kelimeleri kullanma başarısının daha fazla olduğu sonucuna varılabilir.

Tablo 4. Anı ile ilgili tweetlere ilişkin sayısal veriler

\begin{tabular}{|c|c|c|c|}
\hline Öğrenciler & 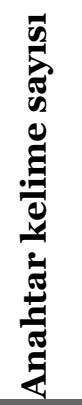 & Öğrenciler & 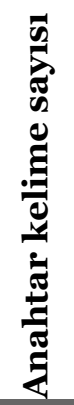 \\
\hline Ö1 & o & Ö19 & 1 \\
\hline Ö2 & 1 & Ö20 & 1 \\
\hline Ö3 & 1 & Ö21 & 2 \\
\hline$\ddot{0}_{4}$ & o & Ö22 & 2 \\
\hline Ö5 & o & Ö23 & 1 \\
\hline Ö6 & 1 & Ö24 & 1 \\
\hline$\ddot{0}_{7}$ & o & Ö25 & c \\
\hline 0̈8 & 1 & Ö26 & $\mathrm{c}$ \\
\hline Ö9 & 1 & Ö27 & $c$ \\
\hline Ö10 & 1 & Ö28 & 1 \\
\hline Ö11 & o & Ö29 & c \\
\hline Ö12 & o & Ö30 & 2 \\
\hline Ö13 & o & Ö31 & 2 \\
\hline Ö14 & 2 & Ö32 & 2 \\
\hline Ö15 & o & Ö33 & 1 \\
\hline
\end{tabular}




\begin{tabular}{|l|c|l|c|}
\hline$\ddot{O}_{16}$ & 0 & $\ddot{O}_{34}$ & 0 \\
\hline$\ddot{O}_{17}$ & 0 & $\ddot{O}_{35}$ & 2 \\
\hline$\ddot{O}_{18}$ & 0 & $\ddot{O}_{36}$ & 1 \\
\hline
\end{tabular}

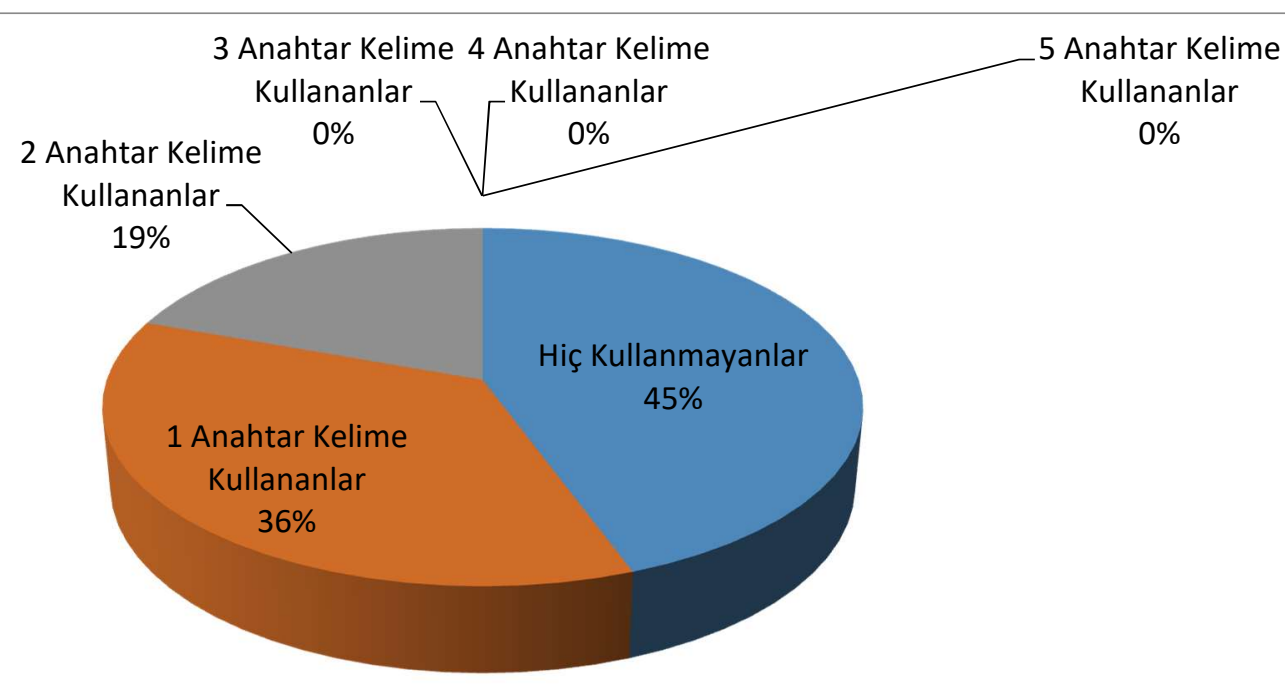

Anı Metni Anahtar Kelime Kullanma Yüzdeliği

\section{Şekil 4: Anı ile ilgili tweetlere ilişkin yüzdelik dağılım}

Anı metnine dair tweetlerde 13 öğrencinin 1 anahtar kelime, 7 öğrencinin 2 anahtar kelime, 16 öğrencinin herhangi bir anahtar kelime kullanmadıkları, 3, 4 ve 5 anahtar kelime kullanan öğrencinin ise bulunmadığı görülmektedir. Öğrencilerin \%36'sı 1 anahtar kelime, \% 19 'u 2 anahtar kelime kullanmış, \%45”i ise hiçbir anahtar kelimeyi kullanmamıştır. Anı metnine dair atılan tweetlerde anahtar kelime kullanmayan öğrenciler ile 1 anahtar kelime kullanan öğrencilerin \%81’i oluşturduğu görülmektedir. Anı metnine dair atılan tweetlerde de öğrencilerin anahtar kelime kullanma başarısının düşük olduğu söylenebilir. 
Tablo 5. Deneme ilgili tweetlere ilişkin sayısal veriler

\begin{tabular}{|c|c|c|c|}
\hline Öğrenciler & 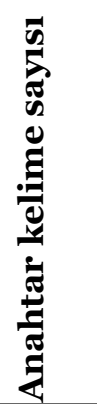 & Öğrenciler & 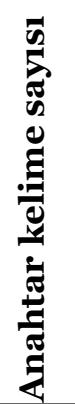 \\
\hline$\ddot{O ̈}_{1}$ & 1 & Ö19 & 3 \\
\hline Ö2 & 1 & Ö20 & 2 \\
\hline$\ddot{0}_{3}$ & 1 & Ö21 & 1 \\
\hline$\ddot{O}_{4}$ & 3 & Ö22 & 2 \\
\hline$\ddot{O}_{5}$ & 2 & Ö23 & 1 \\
\hline Ö6 & 1 & Ö24 & 1 \\
\hline$\ddot{\mathbf{O}}_{7}$ & 2 & Ö25 & 1 \\
\hline 0̈8 & 3 & Ö26 & 1 \\
\hline Ö9 & 3 & Ö27 & 1 \\
\hline Ö10 & 3 & Ö28 & 2 \\
\hline Ö11 & 2 & Ö29 & 3 \\
\hline Ö12 & 1 & $\ddot{0}_{\mathbf{3 0}}$ & 1 \\
\hline Ö13 & 2 & Ö31 & 2 \\
\hline Ö14 & 3 & Ö32 & 3 \\
\hline Ö15 & 2 & Ö33 & 1 \\
\hline Ö16 & 2 & Ö34 & 2 \\
\hline Ö17 & 2 & Ö35 & 3 \\
\hline Ö18 & 3 & $\ddot{O}_{36}$ & 1 \\
\hline
\end{tabular}




\section{Şekil 5. Deneme ile ilgili tweetlere ilişkin yüzdelik dağılım}

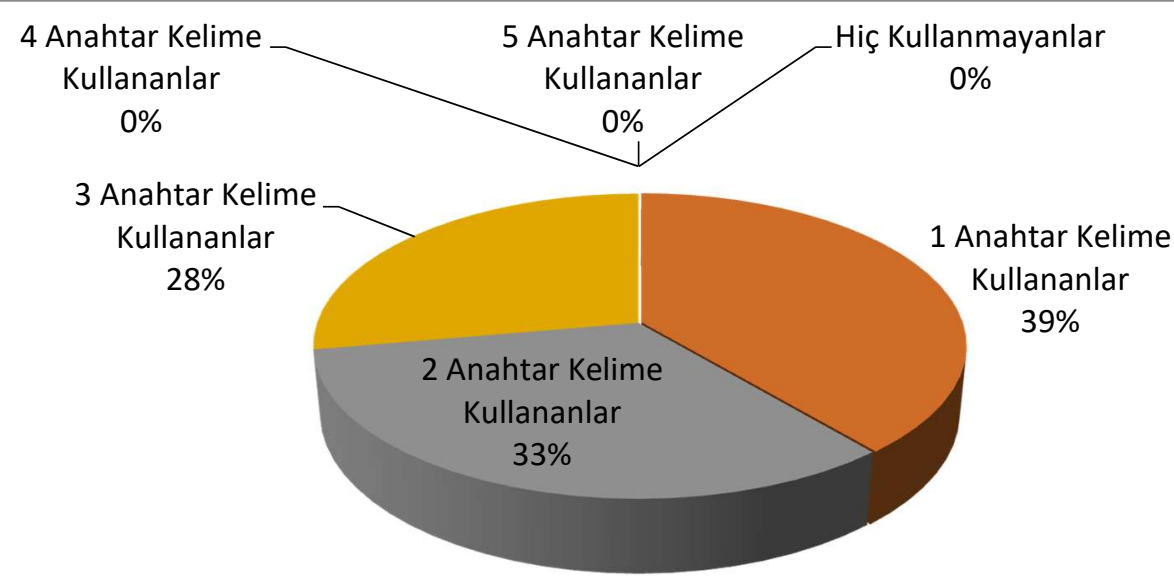

\section{Deneme Metni Anahtar Kelime Kullanma Yüzdeliği}

Deneme metnine dair atılan tweetlerde 14 öğrencinin 1 anahtar kelime, 12 öğrencinin 2 anahtar kelime, 10 öğrencinin 3 anahtar kelime kullandığı görülürken 4 ve 5 anahtar kelime kullanan öğrenci bulunmamaktadır. Ayrıca öğrencilerin \%39'unun 1 anahtar kelime, \%33'ünün 2 anahtar kelime, \%28'nin 3 anahtar kelime kullandıkları görülmektedir. Deneme metnine dair atılan tweetlerde öğrencilerin tamamının en az bir anahtar kelime kullandığı görülmektedir. 4 ve 5 anahtar kelime kullanan öğrenci bulunmasa da atılan tweetlerde anahtar kelime kullanma başarısının yüksek olduğu söylenebilir.

\section{Sonuç}

Okuma becerisi ön bilgilerin harekete geçirildiği bir anlam kurma süreci olarak tanımlanabilir (Akyol, 2010). Okuma becerisinde en önemli hususlardan birisi metnin anlaşılmasını sağlayan anahtar kelimelerdir. Çağrışım gücü yüksek olan bu kelimelerin tespit edilmesi metnin zihinde yapılandırılması açısından önem arz etmektedir. Anlatmaya dayalı bir beceri olan yazma becerisi ise duygu düşünce hayal ve tasavvurların doğru ve estetik biçimde ifade edilmesi esasına dayanır. Temel dil becerilerinin birbirini bütünlediği göz önüne alındığında okuduğunu anlama ve anladığını yazılı olarak ifade etme arasında sıkı bir irtibatın olduğunu söylemek mümkündür. Yirmi birinci yüzyll, teknolojinin insan yaşamını büyük bir oranda etkilediği bir çağ hâline gelmiştir. Bu itibarla kâğıt temelli anlama ve anlatma faaliyetleri yerini ekran temelli okuma ve yazma faaliyetlerine birakmaktadır. Okuma ve yazma eylemleri tabletlerden akıllı telefonlara uzanan geniş bir yelpazede ve elektronik ortamda gerçekleştirilmektedir. Türkçe öğretmeni adaylarının ve okul çağında öğrenim gören öğrencilerin internet ortamlarını sık kullandıkları, sosyal ağ ortamlarında duygu ve düşüncelerini dile getirdikleri çeşitli içerikleri paylaştıkları ve mevcut içeriklere yorum getirdikleri bilinmektedir. Bilgi çă̆ının getirdiği teknolojiye ait yenilikler eğitim ortamlarının ayrılmaz bir bileşeni ve destekleyici bir unsuru hâline gelmiştir. Bu sebeple günümüz öğretmenlerinin ve öğretmen adaylarının bilgi ve iletişim teknolojilerini etkili kullanması gerekmektedir. Başka bir ifadeyle "teknolojik kötümserlik" bakış açısı yerine "teknolojik iyimserlik"in eğitim süreçlerini zenginleştirip daha fazla katkıda bulunabileceği ifade edilebilir. Yukarıda ifade edildiği gibi internet teknolojisinin en yaygın kullanım alanlarından birisi Web 2.0 araçlarıdır. Web 2.0 ortamlarında okuma ve yazma becerileri yaygın olarak işe koşulmakta anlama ve anlatma kaygıları yoğun olarak yaşanmaktadır. Bu bağlamda öğretmenlerin ve öğretmen adaylarının 
öğrencilere elektronik ortamda etkili okuma ve yazma noktasında rehberlik etmesinin gerekliliği ortaya çıkmaktadır.

Türkçe öğretmeni adaylarının tweet atma becerilerini irdeleyen bu araştırmada adayların okudukları beş farklı metin türünden tespit ettikleri ana düşünceleri elektronik ortamda bir Web 2.0 aracı olan Twitter uygulamasının ön gördügü üzere 140 karakter (tweet) ile ifade etmeleri istenmiştir. Adayların metnin asıl anlatmak istediğini yazmaya çalışırken anahtar kelimeleri kullanıp kullanmadıkları göz önünde bulundurulmuştur. Bilindiği üzere anahtar kelimeler "metnin anlaşılmasını ve sonradan hatırlanmasını sağlayan çağrışım gücü yüksek olan” kelimelerdir (MEB, 2006). Metnin anlaşılıp anlaşılmadığını sınama noktasında anahtar kelimelerin kilit rol oynadığı bilinmektedir. Araştırmanın sonuçlarına göre haber metnine dair atılan tweetlerde öğretmen adaylarının \%69'nun en az 1 anahtar kelime kullandığı, \%31'nin hiçbir anahtar kelime kullanmadı̆̆ı görülmüştür. Haber metinleri bir olayı odak noktası olarak kabul eden bilgilendirici metinlerdir. Haber metnine dair atılan tweetlerdeki anahtar kelimeler başarı değişkenine göre ele alındığında Türkçe öğretmeni adaylarının dikkate değer bir başarı ortaya koyamadıkları tespit edilmiştir.

Küçürek öyküye dair atılan tweetlerde Türkçe öğretmen adaylarının \%67'sinin en az bir anahtar kelime kullandığı, \%33'nün hiçbir anahtar kelimeyi kullanmadığı saptanmıştır. Küçürek öyküler Batı Edebiyatı'nda "flash fiction" olarak bilinen anlık kurmaca öykülerdir (Korkmaz ve Deveci, 2011) . Küçürek öyküye dair atılan tweetler başarı değişkenine göre değerlendirildiğinde haber metninde olduğu gibi Türkçe öğretmen adaylarının kayda değer bir başarı sergilemediği görülmüştür.

Köşe yazısına dair atılan tweetlerde Türkçe öğretmen adaylarının \%97'sinin en az bir anahtar kelime kullandığı, \%3’nün hiçbir anahtar kelimeyi kullanmadığı saptanmıştır. Köşe yazıları günlük sosyal olayları konu edinen düşünce yazılarıdır. Köşe yazısına dair atılan tweetler başarı değişkenine göre incelendiğinde öğretmen adaylarının başarılı bir netice elde ettiği ifade edilebilir. Bu durum okutulan bu köşe yazısı metninin güncel bir meseleye dayanması ile izah edilebilir. Öte yandan öğretmen adaylarının Twitter uygulamasında günlük sosyal olaylar ile ilgili paylaşımlara aşina olmasının metni anlama ve anahtar kelimeleri kullanarak anlatmaya çalışmasını kolaylaştırdığı şeklinde yorumlanabilir.

Anı metnine dair atılan tweetlerde Türkçe öğretmen adaylarının \%55’inin en az bir anahtar kelime kullandığı, \%45’inin hiçbir anahtar kelimeyi kullanmadığı görülmüştür. Anılar, yaşantıları konu edinen bilgilendirici metinlerdir. Anı metnine dair atılan tweetler başarı değişkenine göre incelendiğinde öğretmen adaylarının başarılı bir netice yakalayamadıkları saptanmıştır.

Deneme metnine dair atılan tweetlerde Türkçe öğretmen adaylarının tamamının en az bir anahtar kelimeyi kullandığı tespit edilmiştir. Deneme, kişisel düşüncelerin kanıtlama amacı gütmeksizin aktarıldığı metin türüdür. Deneme metnine dair atılan tweetler başarı değişkenine göre incelendiğinde Türkçe öğretmen adaylarının başarılı bir netice elde ettikleri görülmektedir. Deneme türünün doğası itibariyle şahsî düşüncelere dayalı olması, ispat etme endişesinin olmaması ve bilimsel verilerin dayanak olarak gösterilmemesi gibi nitelikleri metnin anlaşılmasını ve anlatılmasını kolaylaştırıcı bir sonuç doğurmuştur. Diğer yandan Türkçe öğretmeni adaylarının sosyal ă̆ ortamlarında kişisel düşüncelerini sürekli ifade etme imkânı bulmalarının anlama ve anlatma becerilerini olumlu yönde etkilediği ileri sürülebilir.

Türkçe öğretmeni adaylarının okudukları metinlerden anladıklarını anahtar kelimeleri kullanarak 140 karakter sınırı içerisinde yazılı olarak ifade edebilme düzeyini ortaya koymayı amaçlayan bu araştırmada 
çalışma grubuna dâhil olan Türkçe öğretmeni adaylarının deneme ve köşe yazısı türlerinde daha başarılı olduğu; haber metni, küçürek öykü ve anı metninde ise başarılarının daha düşük seviyede olduğu tespit edilmiştir. Genel anlamda Türkçe öğretmeni adaylarının 3 ve üzerinde anahtar kelimeyi kullanamadıkları görülmüş bu sebeple yazma becerilerinde okudukları bir metinden hareketle çıkarımlarını yazılı olarak ifade etmede zorlandıkları sonucuna varılmıştır. Alanyazın incelendiğinde Türkçe öğretmeni adaylarının sosyal medyadaki anlama ve anlatma becerilerini konu alan bir çalışmanın olmadığı görülmektedir. Bu itibarla araştırmanın sonuçları başka çalışmaların verileri ile mukayese edilememiştir. Öğretmen adaylarının kâğıt temelli yazma becerilerini konu alan alanyazın incelendiğinde ise araştırma sonuçlarının Arıcı (2008), Bağcı (2010) ve Çamurcu'nun (2011) araştırmalarıyla örtüştüğü söylenebilir.

Çağımızın en çok kullanılan uygulamalarından olan Web 2.0 araçları eğitim ortamlarını ziyadesiyle etkilemektedir. Geleceğin Türkçe öğretmenleri olan Türkçe öğretmeni adaylarının bu araçlarla ilgili farkındalık ve deneyim kazanmaları ve gelecekte kendilerini bu alanlarda etkili bir şekilde ifade etmeleri beklenmektedir. Hem Türkçe öğretmeni adaylarının yeterlilik düzeylerinin tespiti hem de bu alandaki eğitim ihtiyacının belirlenmesi için Türkçe öğretmeni adaylarının, Web 2.0 araçlarında kendilerini yazılı ifade etme becerileri üzerine yeni çalışmalar yapılması gerekli görülmektedir.

\section{Kaynakça}

Akyol, H. (2000). Yazı öğretimi. Millî eğitim dergisi, 146, 37-48.

Akyol, H. (2010). Türkçe Öğretim Yöntemleri. Ankara: Pegem Akademi.

Arıcı, A. F. (2005). İlköğretim ikinci kademe öğrencilerinin okuma durumları (beceri-ilgi-alsşkanlıkeğilim). Yayımlanmamış Doktora Tezi. Atatürk Üniversitesi, Sosyal Bilimler Enstitüsü.

Arıcı, A. F. (2008). Üniversite öğrencilerinin yazılı anlatım hataları. Uludă̆ Üniversitesi Eğitim Fakültesi Dergisi, 21(2), 209-220.

Arıcı, A. F. (2016). Erken çocukluk dil gelişiminde ailenin rolü. Türkiye Eğitim Dergisi, 1(1), 66-78.

Aslan, B. (2007). Web 2.o, teknikleri ve uygulamaları. XII. "Türkiye'de İnternet” Konferansı Bildirileri, 8-10.

Atıcı, B., Yıldırım, S. (2010). Web 2.0 uygulamalarının e-öğrenmeye etkisi. Akademik Bilişim, 10, 10-12.

Aytan, T. ve Başal, A. (2015). Türkçe öğretmen adaylarının Web 2.0 araçlarına yönelik algılarının incelenmesi. Turkish Studies, 10(7), 149-166.

Aytaş, G. (2005). Okuma eğitimi. Türk Eğitim Bilimleri Dergisi, 3(4), 461-470.

Bağcı, H. (2010). Türkçe öğretmeni adaylarının yazılı anlatım yeterlilik düzeyleri. İnönü Üniversitesi Eğitim Fakültesi Dergisi. 11(2), 45-68.

Çamurcu, D. (2011). Yüksek öğrenimine yeni başlayan Türkçe eğitimi bölümü öğrencilerinin yazma becerilerinin incelenmesi. Selçuk Üniversitesi Türkiyat Araşttrmaları Dergisi, 1(29), 503-518.

Deperlioğlu, Ö., Köse, U. (2010). Web 2.0 teknolojilerinin eğitim üzerindeki etkileri ve örnek bir öğrenme yaşantısı. Akademik Bilişim, 10-12.

Gülbahar, Y., Kalelioğlu, F., Madran, O. (2010). Sosyal ağların eğitim amaçlı kullanımı. XV. Türkiye'de İnternet Konferansı, İTÜ, İstanbul.

Güneş, F. (1994). Okur-yazarlık kavramı ve düzeyleri. Ankara Üniversitesi Eğitim Bilimleri Fakültesi Dergisi, 27(2), 499-507.

Günüç, S., Odabaşı, H. F. ve Kuzu, A. (2013). 21. yüzyıl öğrenci özelliklerinin öğretmen adayları tarafından tanımlanması: Bir Twitter uygulaması. Eğitimde Kuram ve Uygulama, 9(4), 436-455. 
A Study on Writing Tweet Skills of Turkish Language Teacher Candidates / T. Aytan, G. Güneş, M. A. Çalıcı (p. 42-58)

Horzum, M. B. (2010). Öğretmenlerin Web 2.0 araçlarından haberdarlığı, kullanım sıklıkları ve amaçlarının çeşitli değişkenler açısından incelenmesi. Uluslararası İnsan Bilimleri Dergisi, 7(1), 603-634.

Karademir, T. ve Alper, A. (2011). Ö̆̆renme ortamı olarak sosyal ağlarda bulunması gereken standartlar.

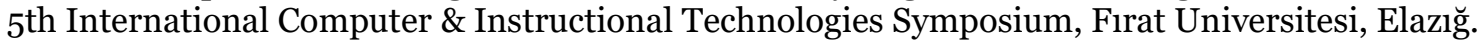

Karatay, H. (2010). İlköğretim öğrencilerinin okuduğunu kavrama ile ilgili bilişsel farkındalıkları. Türklük Bilimi Araştırmaları, 27(27), 457-475.

Kavcar, C., Oğuzkan, F., Sever S. (1998), Türkçe öğretimi-Türkçe ve sinıf öğretmenleri için, Ankara: Engin.

Koç, A. ve Ayık, Y. Z. (2017). Sosyal medya destekli eğitim: 6. ve 7. sınıf fen bilimleri ve İngilizce derslerinde sosyal ağ kullanımının öğrencilerin akademik başarılarına etkisi. Avrupa Bilim ve Teknoloji Dergisi, 6(10), 7-19.

Korkmaz, R. Deveci, M. (2011), Türk edebiyatında yeni bir tür küçürek öykü, Ankara: Grafiker.

Köse, U., Çal, Ö. (2012). Web 2.o servislerinin sosyolojik değerlendirilmesi. XIV. Akademik Bilişim Konferansı Bildirileri, 1-3.

Kurudayığlu, M., Kana, F. (2013). Türkçe öğretmeni adaylarının dinleme becerisi ve dinleme eğitimi özyeterlik algıları. Mersin Üniversitesi Eğitim Fakültesi Dergisi, 9(2), 245-258.

Kuzu, E. B. (2014). Bilişim teknolojileri öğretmen adayları arašnda çevrimiçi sosyal ağların öğretim amaçlı kullanımı. Yayımlanmamış doktora tezi. Anadolu Üniversitesi, Eğitim Bilimleri Enstitüsü.

Melanlıŏ̆lu, D. (2012). Dinleme becerisinin geliştirilmesinde ailenin rolü. Sosyal Politika Çalışmaları Dergisi, 7(29), 65-77.

Millı̂ Eğitim Bakanlığı (2006). Türkçe dersi (1-8.sınıflar) öğretim programı. Ankara: Millî Eğitim Bakanlığı.

Millî Eğitim Bakanlığı. (2017). 5.sınıf Türkçe ders kitabı. Ankara: MEB Yayınları (1.Baskı).

Millî Eğitim Bakanlığı (2017). Türkçe dersi (1-8. sımıflar) öğretim programı. Ankara: Millî Eğitim Bakanlığı.

Millî Eğitim Bakanlığı (2018). Türkçe dersi (1-8. sınıflar) öğretim programı. Ankara: Millî Eğitim Bakanlığı.

Odabaşı, H. F., Mısırlı, Ö., Günüç, S., Timar, Z. Ş., Ersoy, M., Seçil, S., Dönmez, F. İ., Akçay, T. Erol, O. (2012). Eğitim için yeni bir ortam: Twitter. Anadolu Journal of Educational Sciences International, 2(1).

Özbaş Anbarlı, Z. (2017). Dijital uzamda yaşamak: Twitter'da gündelik hayat. Yayımlanmamış doktora tezi. Anadolu Üniversitesi, Sosyal Bilimler Enstitüsü.

Özdemir, O. (2017). Türkçe öğretiminde dijital teknolojilerin kullanımı ve bir web uygulaması örneği. Turkish Studies, 12(4), 427-444.

Özerbaş, M. A. ve Akın Mart, Ö. (2017). İngilizce öğretmen adaylarının Web 2.o kullanımına ilişkin görüş ve kullanım düzeyleri. Ahi Evran Üniversitesi Kırşehir Eğitim Fakültesi Dergisi, 18(3).

Saraçoğlu, A. (2000). Dil ve edebiyat terimleri sözlüğü. Eskişehir: Etam A.Ş.

Sever, S. (2004), Türkçe öğretimi ve tam öğrenme. Ankara: Anı.

Süğümlü, Ü. (2013), "Avustralya İngilizce öğretim programı" (s. 169-198), Dünyada ana dili öğretimi program incelemeleri-, (Editör: Havva Yaman), Ankara: PegemA.

Umagan, S. (2007). Dinleme Eğitimi. A. Kırkkılıç ve H. Akyol, (Ed.), İlköğretimde Türkçe öğretimi,(149163). Ankara: PegemA.

Wagner, T. (2008). Rigor redefined. Educational Leadership, 66(2), 20-24. 